\title{
Efficacy of different levels of Escherichia coli phytase in hens fed maize-soyabean meal based diets with a decreased non-phytate phosphorus content*
}

\author{
K. Kozłowski ${ }^{1}$ and H. Jeroch \\ University of Warmia and Mazury, Department of Poultry Science \\ Oczapowskiego 5, 10-718 Olsztyn, Poland
}

(Received 7 March 2011; revised version 22 April 2011; accepted 18 June 2011)

\begin{abstract}
The aim of this experiment was to determine the efficacy of different inclusion levels of new type phytase (ECP) synthesized by Escherichia coli and expressed in Pichia pastoris yeast (Optiphos) in maize-soyabean meal based diets on egg quality and the laying performance of laying hens aged from 20 to 44 weeks. Two hundred and twenty Lohmann Brown hens were randomly assigned to five treatments with 44 replicates each, and were kept individually in cages. The control diet (C) contained $2.5 \mathrm{~g}$ non-phytate phosphorus (NPP) and $35.5 \mathrm{~g} \mathrm{Ca} / \mathrm{kg}$ feed, and the experimental diets contained $1.3 \mathrm{~g} \mathrm{NPP}$ and $33.0 \mathrm{~g} \mathrm{Ca} / \mathrm{kg}$ feed. The deficient diet (D) was offered without any addition of phytase, while the other treatments involved different levels of this enzyme: 125, 250 and 500 $\mathrm{FTU} / \mathrm{kg}$ feed (treatments $\mathrm{ECP}_{125}, \mathrm{ECP}_{250}$ and $\mathrm{ECP}_{500}$, respectively). Compared with the deficient diet, phytase supplementation significantly affected the performance of hens over the entire experimental period (number of eggs laid, egg mass and FCR), and egg quality parameters: egg yolk colour (significantly in week 24 of the laying period) and shell thickness (significantly in week 12 of the laying period).

The results of the present study indicate that the supplementation of diets for laying hens with ECP improved performance parameters. The NPP content of layer diets based on maize meal and soyabean meal can be reduced by $1.2 \mathrm{~g} / \mathrm{kg}$ provided that the diets are supplemented with ECP at 125-250 FTU per kg diet.
\end{abstract}

KEY WORDS: laying hens, phytase, performance, egg quality

\footnotetext{
* Supported by HUVEPHARMA NV (Antwerp/Belgium)

${ }^{1}$ Corresponding author: e-mail: kristof@uwm.edu.pl
} 


\section{INTRODUCTION}

The main components of diets for poultry are cereal grains, legume seeds, fat-rich seeds and the by-products of plant food processing. Most of phosphorus (from 50 to $80 \%$ ) is present in complexes with phytic acid (Ravindran et al., 1995; Oloffs et al., 2000a; Singh, 2008). This phosphorus is available to laying hens or other birds only if the enzyme phytase is present in their digestive tract. Laying hens produce very small amounts of phytase, and phytase production by microorganisms in the gastrointestinal tract is also limited (Maenz and Classen, 1998; Marounek et al., 2008). Only the grains of selected cereals (barley, wheat, triticale, rye) contain phytase whose activity is partly sufficient to hydrolyse phytin (Eeckhout and De Pappe, 1994; Oloffs et al., 2000b). Seed plants, including maize, show minimal activity levels of phytase (Selle and Ravindran, 2007). Total phosphorus contained in wheat is available to laying hens in nearly $50 \%$, whereas the respective value for maize is as low as 20\% (Oloffs et al., 2000a). Due to the breeding of early-maturing and high-yielding varieties, the area under maize cultivation has increased recently also in countries (including Poland) and regions where it had been produced on a very small scale before. Maize is a widely used ingredient in poultry diets. Phytate complexes present in this feed component can be reduced with the use of exogenous phytases, i.e. the new 6-phytase derived from Escherichia coli. The utilization of phosphorus contained in maize may be increased if diets are supplemented with microbial E. coli phytase (Wu et al., 2006; Augspurger et al., 2007; Liu et al., 2007; Hughes et al., 2008). In Poland, the effect of Escherichia coli phytase (ECP) supplementation on performance parameters has been studied in broilers and young turkeys (Kozłowski et al., 2009, 2010a,b), but not in laying hens. The level of phytase supplementation of phosphorusdeficient diets can be two-fold lower in laying hens than in broilers. The results of numerous experiments show that a maize-soyabean meal diet containing no added phosphorus and $300 \mathrm{FTU} / \mathrm{kg}$ phytase can be fed for as long as 40-50 weeks with no deleterious effects on egg production performance (Van der Klis et al., 1997; Boling et al., 2000; Hughes et al., 2008).

The aim of the present experiment was to determine the effect of different inclusion levels of ECP in maize-soyabean meal diets. Such diets contain approximately $50 \%$ of the recommended non-phytate phosphorus level (Smulikowska and Rutkowski, 2005). Phytase efficacy was estimated based on the performance of laying hens and egg quality parameters. 


\section{MATERIAL AND METHODS}

\section{Animals and dietary treatments}

The experimental materials comprised a total of 220 Lohmann Brown hens from a commercial pullet grower house, aged 18 weeks, grown in accordance with the breeder's recommendations (LTZ, 2010). The hens were randomly divided into five treatments ( 44 replicates in each, 1 hen $=1$ replicate) and were kept in individual cages $(30 \times 60 \mathrm{~cm})$ during the first 24 weeks of the laying period (from 20 to 44 weeks of age). The replicates were equally distributed among three cage levels to minimize the cage level effect. The birds were housed in an environmentally controlled house with a day length of $15 \mathrm{~h}$ light: $9 \mathrm{~h}$ dark. All experimental procedures involving animals were approved by the local Animal Experimentation Ethics Committee (decision no. 12/2007) at the University of Warmia and Mazury in Olsztyn.

The diets, offered ad libitum in meal form, were formulated so as to meet the nutrient and energy requirements of laying hens (Smulikowska and Rutkowski, 2005). Diet composition is presented in Table 1. Two maize-soyabean meal based diets were produced as follows: a control diet (C) followed by a deficient diet (D) divided into four identical parts. The diet for the control (C) group had an identical nutritional value as diets for the remaining treatments, except for the concentrations of calcium and phosphorus $(\mathrm{Ca}-35.5 \mathrm{~g} / \mathrm{kg}$, NPP $-2.5 \mathrm{~g} / \mathrm{kg})$. The deficient (D - negative control) group received a diet with a lower content of calcium and phosphorus $(\mathrm{Ca}-33.0 \mathrm{~g} / \mathrm{kg}$, NPP $-1.3 \mathrm{~g} / \mathrm{kg})$. Diets in treatments $\mathrm{ECP}_{125}, \mathrm{ECP}_{250}$ and $\mathrm{ECP}_{500}$ had the same composition as the D diet, but were supplemented with different concentrations of Escherichia coli-derived 6-phytase expressed in Pichia pastoris (Optiphos, HUVEPHARMA NV, Belgium). Phytase was supplemented as a $1 \%$ premix. Escherichia coli phytase was added to diets in treatments $\mathrm{ECP}_{125}, \mathrm{ECP}_{250}$ and $\mathrm{ECP}_{500}$ in the following amount: 125, 250 and 500 FTU/kg of diet, respectively.

Feed samples were analysed by the following methods: samples were mineralized in a mixture of nitric acid and perchloric acid (3:1) (Merck, Germany). Mineralization was carried out in an aluminum heating block with temperature control (VELP DK 20, VELP Scientifica, Italy). Reference samples were prepared together with test samples. The Ca content of mineralizates was determined by flame atomic absorption spectrometry (acetylene-air flame), with the use of a Unicam 939 atomic absorption spectrometer (Solar, UK), equipped with an Optimus data station, a background correction source (deuterium lamp) and cathode lamps (Whiteside and Milner, 1984). In order to determine Ca 
Table 1. Composition of the basal diet

\begin{tabular}{lcc}
\hline \multirow{2}{*}{ Item } & \multicolumn{2}{c}{ Treatments } \\
\cline { 2 - 3 } Ingredient, $\%$ & control & deficient and ECP \\
maize & 59.99 & 61.88 \\
sunflower meal & 5.00 & 5.00 \\
soyabean meal, 48\% CP & 22.50 & 22.20 \\
soyabean oil & 0.50 & 0.50 \\
animal fat & 1.50 & 0.85 \\
NaHCO & 0.15 & 0.15 \\
salt & 0.22 & 0.22 \\
limestone & 9.00 & 8.60 \\
monocalcium phosphate & 0.54 & - \\
DL-methionine & 0.10 & 0.10 \\
Premix ${ }^{1}$ & 0.50 & 0.50 \\
Calculated energy and nutrient content, $\%$ & & \\
AME ${ }_{\mathrm{N}}$ MJ/kg & $11.45^{2}$ & $11.45^{2}$ \\
crude protein & $17.11^{2} / 17.68^{3}$ & $17.14^{2} / 17.60^{3}$ \\
crude fat & $4.70^{2}$ & $4.13^{2}$ \\
crude fibre & $3.30^{2}$ & $3.33^{2}$ \\
Na & $0.15^{2}$ & $0.15^{2}$ \\
Ca & $3.55^{2} / 3.75^{3}$ & $3.30^{2} / 3.50^{3}$ \\
P (total) & $0.46 / 0.49^{3}$ & $0.35 / 0.39^{3}$ \\
NPP & 0.25 & 0.13 \\
\hline
\end{tabular}

${ }^{1}$ provided per $\mathrm{kg}$ of diet, IU: vit. A 8,000, vit. $\mathrm{D}_{3} 2,000$; mg: vit. $\mathrm{E} 20$, vit. $\mathrm{K}_{3}$ 1, thiamine 1.5 , riboflavin 4 , pyridoxine 1 , biotin 0.1 , pantothenic acid 6 , folic acid 0.5 , niacin 20 , vit. $\mathrm{B}_{12} 0.02$, I $0.7, \mathrm{Se} 0.15, \mathrm{Cu} 6, \mathrm{Mn} \mathrm{65,} \mathrm{Zn} \mathrm{52,} \mathrm{Fe} \mathrm{45;}{ }^{2}$ calculated (Smulikowska and Rutkowski, 2005); ${ }^{3}$ analysed (Naumann and Bassler, 1993); ${ }^{4} \mathrm{NPP}$ - non-phytate phosphorus

content, a $10 \%$ aqueous solution of lanthanum chloride was added to all experimental solutions, in the amount ensuring the final $\mathrm{La}^{+3}$ concentration of $1 \%$. Phosphorus concentration was determined in mineralizates by colorimetry with ammonium molybdate and with sodium sulphate and hydroquinone. Absorbance was measured using a VIS 6000 spectrophotometer (KRÜSSOPTRONIC, Germany), at a wavelength of $\lambda=610 \mathrm{~nm}$ (Fiske and Subbarow, 1925). $\mathrm{Ca}$ and $\mathrm{P}$ content was determined using standards at a concentration of $1 \mathrm{mg} / \mathrm{cm}^{3}$, diluted with a $0.1 \mathrm{M}$ solution of $\mathrm{HNO}_{3}$ (BDH, Germany).

Phytase activity in all experimental diets was analysed in triplicate according to Han et al. (1999). The trial began after the confirmation that the actual concentrations of the experimental diets were in compliance with the target levels for each treatment group.

\section{Production parameters and egg quality}

The body weight of all layers was measured two times: at the beginning (week 
20) and at the end of the experimental period (week 44). Feed consumption was recorded weekly to calculate the average daily feed intake. Eggs were collected three times a week (on Monday, Wednesday and Friday). Egg weight was determined at two-week intervals, using all eggs from one collection (produced during two consecutive days). Egg mass ( $\mathrm{kg}$ of eggs per hen per laying period) and feed conversion ratio (feed/egg mass) were calculated based on egg production, egg weight and feed consumption.

Egg quality parameters were determined using 10 eggs selected randomly from each treatment in the middle and at the end of the experiment. The eggs were weighed, then broken, and yolk colour and albumen quality were determined. Yolk colour was scored with the aid of a Roche Yolk Color Fan (F. Hoffman - La Roche Ltd., Switzerland). The Haugh units were calculated using an EMT-5200 egg multitester (Robotmation Co. Ltd., Tokyo, Japan) based on albumen height and egg weight, according to the following formula:

$$
\mathrm{HU}=100 \log _{10}\left(\mathrm{H}-1.7 \mathrm{~W}^{0.37}+7.56\right)
$$

where: HU - Haugh unit, $\mathrm{H}$ - albumen height (mm), W - egg weight (g).

The yolks were separated from the albumen, and the chalaza was removed with scissors. Each yolk was then rolled on a paper towel to remove the adhering albumen. Albumen weight was calculated by subtracting the weight of the yolk and shell from total egg weight. Egg shells were cleaned of any adhering albumen and dried. After removing the egg membranes, eggshell thickness was measured using a digital display micrometer gauge with spherical tips (Mitutoyo 395-741-10, 7301, Japan). Eggshell thickness was a mean value of measurements performed at three locations on the egg (air cell, equator and sharp end).

Shell strength was measured only once (at the end of the experiment) on 10 eggs selected for egg quality determination, using a Universal Testing Machine (EZ Test, Shimadzu, Japan). At the end of experiment 10 birds of each treatments were killed by cervical dislocation and toe ash content was obtained.

\section{Statistical analysis}

The results of the experiment were analysed using a one-way analysis of variance (ANOVA), and significant differences between groups were determined with Duncan's multiple range test. Differences were considered significant at $\mathrm{P}<0.05$. The Statistica software package version 9.0 (StatSoft Inc., 2009) was used for statistical calculations. 


\section{RESULTS AND DISCUSSION}

A proximate feed analysis showed that the actual nutrient concentrations were consistent with the calculated values listed in Table 1 . The results of an analysis of phytase activity in the diets is shown in Table 2. They were satisfactory and corresponded with the target values.

Table 2. The activity of $E$. coli phytase in experimental diets, FTU/kg of diet

\begin{tabular}{lrcccc}
\hline \multirow{2}{*}{ Item } & \multicolumn{5}{c}{ Treatments } \\
\cline { 2 - 6 } & $\mathrm{C}^{1}$ & $\mathrm{D}^{2}$ & $\mathrm{ECP}_{125}^{3}$ & $\mathrm{ECP}_{250}$ & $\mathrm{ECP}_{500}$ \\
\hline Expected values & 0 & 0 & 125 & 250 & 500 \\
Analysed values & 20 & 9 & 114 & 236 & 483 \\
\hline
\end{tabular}

control group; ${ }^{2}$ deficient group; ${ }^{3}$ Escherichia coli phytase

The birds from all treatments were characterized by a very good, $100 \%$ liveability. There were no differences in the average body weight of laying hens between treatments at the beginning of the experiment (week 20), but significant differences were noted in week 24 of the laying period (Table 3). Before the

Table 3. The effect of NPP and E. coli phytase on the body weight and weight gains of hens

\begin{tabular}{|c|c|c|c|c|c|c|c|}
\hline \multirow{2}{*}{ Item } & \multicolumn{5}{|c|}{ Treatments } & \multirow{2}{*}{ SEM } & \multirow{2}{*}{$\mathrm{P}$} \\
\hline & $\mathrm{C}^{1}$ & $\mathrm{D}^{2}$ & $\mathrm{ECP}_{125}{ }^{3}$ & $\mathrm{ECP}_{250}$ & $\mathrm{ECP}_{500}$ & & \\
\hline \multicolumn{8}{|l|}{ Body weight, $\mathrm{kg}$} \\
\hline beginning of the experiment & 1.439 & 1.477 & 1.425 & 1.428 & 1.418 & 0.007 & 0.070 \\
\hline end of the experiment & $1.997^{\mathrm{a}}$ & $1.820^{\mathrm{b}}$ & $1.934^{\mathrm{ac}}$ & $1.922^{\mathrm{c}}$ & $1.944^{\mathrm{ac}}$ & 0.011 & 0.000 \\
\hline \multicolumn{8}{|l|}{ Body weight gain, $\mathrm{kg}$} \\
\hline 20 to $44 \mathrm{wk}$ & $0.561^{\mathrm{a}}$ & $0.373^{\mathrm{b}}$ & $0.507^{\mathrm{a}}$ & $0.492^{\mathrm{a}}$ & $0.529^{\mathrm{a}}$ & 0.011 & 0.000 \\
\hline
\end{tabular}

experiment, all birds weighed over $1.4 \mathrm{~kg}$ (from $1.418 \mathrm{~kg}$ - treatment $\mathrm{ECP}_{500}$ to $1.477 \mathrm{~kg}$ - treatment D) and after 24 weeks of the laying period the body weight of birds in the $\mathrm{D}$ group was significantly $(\mathrm{P}<0.001)$ lower compared with the other treatments. As a consequence, the body weight gains of treatment D birds were significantly lower in comparison with the body weight gains of hens in the other treatments $(\mathrm{P}<0.001)$. This is consistent with the findings of Beutler (2009) who demonstrated that hens fed a $0.15 \%$ NPP diet (P deficient) without phytase supplementation had significantly reduced body weight at the end of the trial in comparison with the $\mathrm{C}$ and the D diet supplemented with 400-600 FTU E. coli phytase. Similar results were reported by Augspurger et al. (2007) who found that $E$. coli phytase supplementation of a $0.10 \%$ NPP diet, in the amount of 150-10.000 FTU/kg, caused a significant decrease in the body weight of hens, but only until week 4 of the laying period. Also Boling et al. (2000) reported a significant decrease in the body weight (until week 40 of age) of hens fed 
a $0.10 \%$ NPP diet, compared with birds fed a phytase-supplemented diet (300 FTU). Oloffs et al. (1997) noted a reduction in the body weight of hens fed a diet containing 1.1-1.3 g NPP/kg feed. An improvement in the body weight gains of birds was observed when diets were supplemented with phytase (Jeroch and Peter, 1994; Van der Klis et al., 1997; Wu et al., 2006). The question that arises is why phosphorus deficiency causes a decrease in body weight and daily gains. In the present study, feed consumption were similar in all treatments, i.e. energy and nutrient utilization did not change. The reason for the above may be that phosphorus, as a component of energy-rich phosphates (e.g., ATP), plays a key role in fat, protein and carbohydrate metabolism.

There were no differences between treatments in the number of eggs laid during the first 12 weeks of the experiment, but over the entire experimental period birds of the $\mathrm{C}$ and phytase-supplemented treatments $\mathrm{ECP}_{125}$ and $\mathrm{ECP}_{250}$ produced significantly more eggs than hens of the D treatment (Table 4). From the beginning of the experiment until week 24 of the laying period, average egg weight was lowest in D treatment compared with the other treatments. At the end of the experiment, the highest egg weight was observed in $\mathrm{C}$ and $\mathrm{ECP}_{500}$ treatments, and the noted values were around $1.8 \%$ higher than in the D treatment. The observed differences were statistically non-significant. No statistical differences in laying intensity were observed during the first half of the laying

Table 4. The effect of NPP and E. coli phytase on egg number, egg weight, laying intensity and egg mass

\begin{tabular}{|c|c|c|c|c|c|c|c|}
\hline \multirow{2}{*}{ Item } & \multicolumn{5}{|c|}{ Treatments } & \multirow[b]{2}{*}{ SEM } & \multirow[b]{2}{*}{$\mathrm{P}$} \\
\hline & $\mathrm{C}^{1}$ & $\mathrm{D}^{2}$ & $\mathrm{ECP}_{125}{ }^{3}$ & $\mathrm{ECP}_{250}$ & $\mathrm{ECP}_{500}$ & & \\
\hline \multicolumn{8}{|l|}{ Number of eggs } \\
\hline 20 to $32 \mathrm{wk}$ & 78.2 & 77.5 & 79.9 & 79.7 & 79.0 & 0.346 & 0.147 \\
\hline 33 to $44 \mathrm{wk}$ & $79.8^{\mathrm{a}}$ & $75.3^{b}$ & $79.1^{\mathrm{a}}$ & $79.1^{\mathrm{a}}$ & $77.7^{\mathrm{ab}}$ & 0.515 & 0.049 \\
\hline 20 to $44 \mathrm{wk}$ & $158.0^{\mathrm{a}}$ & $152.7^{\mathrm{b}}$ & $159.0^{\mathrm{a}}$ & $158.7^{\mathrm{a}}$ & $156.7^{\mathrm{ab}}$ & 0.728 & 0.044 \\
\hline \multicolumn{8}{|l|}{ Egg weight, $g$} \\
\hline 20 to $32 \mathrm{wk}$ & 60.0 & 59.2 & 59.5 & 60.0 & 60.1 & 0.250 & 0.732 \\
\hline 33 to $44 \mathrm{wk}$ & 64.2 & 62.9 & 63.4 & 63.6 & 64.3 & 0.276 & 0.460 \\
\hline 20 to $44 \mathrm{wk}$ & 62.1 & 61.0 & 61.5 & 61.7 & 62.1 & 0.255 & 0.626 \\
\hline \multicolumn{8}{|l|}{ Laying rate, $\%$} \\
\hline 20 to $32 \mathrm{wk}$ & 93.1 & 92.2 & 95.1 & 94.8 & 94.0 & 0.415 & 0.159 \\
\hline 33 to $44 \mathrm{wk}$ & $95.0^{\mathrm{a}}$ & $89.1^{b}$ & $94.1^{\mathrm{a}}$ & $94.1^{\mathrm{a}}$ & $92.6^{\mathrm{ab}}$ & 0.605 & 0.019 \\
\hline 20 to $44 \mathrm{wk}$ & $94.1^{\mathrm{a}}$ & $90.6^{\mathrm{b}}$ & $94.6^{\mathrm{a}}$ & $94.5^{\mathrm{a}}$ & $93.3^{\mathrm{a}}$ & 0.428 & 0.016 \\
\hline \multicolumn{8}{|c|}{ Egg mass, $\mathrm{kg} / \mathrm{hen}$} \\
\hline 20 to $32 \mathrm{wk}$ & $4.625^{\mathrm{ab}}$ & $4.517^{\mathrm{b}}$ & $4.694^{\mathrm{a}}$ & $4.692^{\mathrm{a}}$ & $4.665^{\mathrm{a}}$ & 0.020 & 0.033 \\
\hline 33 to $44 \mathrm{wk}$ & $5.139^{\mathrm{a}}$ & $4.744^{b}$ & $5.019^{\mathrm{a}}$ & $5.029^{\mathrm{a}}$ & $4.987^{\mathrm{a}}$ & 0.033 & 0.004 \\
\hline 20 to $44 \mathrm{wk}$ & $9.764^{\mathrm{a}}$ & $9.261^{\mathrm{b}}$ & $9.713^{\mathrm{a}}$ & $9.721^{\mathrm{a}}$ & $9.652^{\mathrm{a}}$ & 0.046 & 0.003 \\
\hline
\end{tabular}


period. Throughout the entire experimental period, laying rate was lowest in the $\mathrm{D}$ group. Compared with treatment $\mathrm{D}$, the values of this response parameter in the other groups were by approximately $3.9 \%$ (treatment $\mathrm{C}$ ), $4.4 \%$ (treatment $\mathrm{ECP}_{125}$ ), $4.3 \%$ (treatment $\mathrm{ECP}_{250}$ ) and $3.0 \%$ (treatment $\mathrm{ECP}_{500}$ ) higher.

Hens fed diets with a higher level of phosphorus (C) or diets supplemented with ECP produced significantly $(\mathrm{P}<0.01)$ higher egg mass during the entire laying period, compared with the D treatment (Table 4). Egg mass in those treatments was from $4.2 \%$ (treatment $\mathrm{ECP}_{500}$ ) to $5.4 \%$ (treatment $\mathrm{C}$ ) higher than in D treatment. Simons and Versteegh (1993) noted that phytase added to layer diets had a positive effect on egg weight. Boling et al. (2000) reported that feeding laying hens a maize-soyabean meal based diet (NPP 0.10-0.20\%) supplemented with $300 \mathrm{FTU}$ phytase/kg diet over a 50-week laying period had no significant effects on egg size and egg production.

Egg production results in treatment D clearly indicate that the NPP content of the diet was insufficient to meet the phosphorus requirements of laying hens. It can be assumed, that the diet supplementation with phytase supported the hydrolysis of phytate phosphorus, thus providing birds with adequate quantities of phosphorus. The phytase was effective even at the lowest concentration, which shows that the effect was not dose-dependent. It is in agreement with other researchers, who also obtained significantly lower egg production in P deficient treatments (Boling et al., 2000; Augspurger et al., 2007; Liu et al., 2007).

Feed consumption levels were optimal and typical of Lohmann Brown hens (LTZ, 2010). There were no significant differences between experimental treatments in this respect (Table 5). The relatively low NPP content in the deficient diet (D) had no adverse effect on feed intake. Phosphorus deficiency in laying hens is known to reduce feed consumption. In experiments of some authors (Jeroch and Peter, 1994; Augspurger et al., 2007; Liu et al., 2007) a significant decrease in feed intake in hens fed diets based on maize as a grain source that were not supplemented with dietary phytase was obtained, in case the NPP content ranged from 1.0 to $1.5 \mathrm{~g} / \mathrm{kg}$ and it was substantially lower than recommended by the NRC (1994). Different results were reported by Vogt (1992) who demonstrated that a maize-soyabean diet containing only $1.2 \mathrm{~g}$ $\mathrm{NPP} / \mathrm{kg}$ had no negative influence on feed intake in layers. In this context, the results obtained in the present study suggest that $\mathrm{D}$ treatment hens were not extremely phosphorus-deficient.

Throughout the entire laying trial, hens fed a D diet consumed the highest amount of feed in comparison with the other treatments, but the noted differences were statistically non-significant (Table 5). This is consistent with the findings of other authors who found that feed intake increased in hens fed diets containing $0.1 \%$ NPP supplemented with $A$. niger phytase (Gordon and Roland, 1997; Jalal and Scheideler, 2001). 
Table 5. The effect of NPP and E. coli phytase on feed intake and feed conversion ratio (FCR)

\begin{tabular}{|c|c|c|c|c|c|c|c|}
\hline \multirow[b]{2}{*}{ Item } & \multicolumn{5}{|c|}{ Treatments } & \multirow[b]{2}{*}{ SEM } & \multirow[b]{2}{*}{$\mathrm{P}$} \\
\hline & $\mathrm{C}^{1}$ & $\mathrm{D}^{2}$ & $\mathrm{ECP}_{125}{ }^{3}$ & $\mathrm{ECP}_{250}$ & $\mathrm{ECP}_{500}$ & & \\
\hline \multicolumn{8}{|c|}{ Feed intake, g/hen } \\
\hline 20 to $32 \mathrm{wk}$ & 120.8 & 122.1 & 121.6 & 121.7 & 122.2 & 0.510 & 0.917 \\
\hline 33 to $44 \mathrm{wk}$ & 128.3 & 133.3 & 130.9 & 131.2 & 132.8 & 0.777 & 0.269 \\
\hline 20 to $44 \mathrm{wk}$ & 124.5 & 127.7 & 126.8 & 126.5 & 127.5 & 0.598 & 0.462 \\
\hline \multicolumn{8}{|c|}{ FCR, kg feed/ egg mass } \\
\hline 20 to $32 \mathrm{wk}$ & 2.21 & 2.27 & 2.19 & 2.18 & 2.21 & 0.014 & 0.310 \\
\hline 33 to $44 \mathrm{wk}$ & $2.11^{\mathrm{a}}$ & $2.39^{c}$ & $2.22^{\mathrm{ab}}$ & $2.21^{\mathrm{ab}}$ & $2.25^{\mathrm{b}}$ & 0.021 & 0.001 \\
\hline 20 to $44 \mathrm{wk}$ & $2.16^{\mathrm{a}}$ & $2.33^{\mathrm{b}}$ & $2.20^{\mathrm{a}}$ & $2.19^{\mathrm{a}}$ & $2.23^{\mathrm{a}}$ & 0.015 & 0.005 \\
\hline
\end{tabular}

${ }_{\mathrm{a}, \mathrm{b}}$ means within a row with no common superscripts differ significantly $(\mathrm{P}<0.05) ;{ }^{1,2,3}$ as in Table 1

Throughout the entire experimental period (20-44 weeks), the values of feed conversion ratio calculated for one $\mathrm{g}$ of egg (Table 5) were much better in the control and in all phytase-supplemented treatments $\left(\mathrm{ECP}_{125}-\mathrm{ECP}_{500}\right)$ compared with the $\mathrm{D}$ group, reaching $7.3 \%$ in group $\mathrm{C}, 5.6 \%$ in treatment $\mathrm{ECP}_{125}, 6.0 \%$ in treatment $\mathrm{ECP}_{250}$ and about $4.3 \%$ in treatment $\mathrm{ECP}_{500}$.

The results of an analysis of egg quality parameters are shown in Table 6.

Table 6 . The effect of NPP and E. coli phytase on egg composition, egg quality and toe ash

\begin{tabular}{|c|c|c|c|c|c|c|c|}
\hline \multirow[b]{2}{*}{ Item } & \multicolumn{5}{|c|}{ Treatments } & \multirow[b]{2}{*}{ SEM } & \multirow[b]{2}{*}{$\mathrm{P}$} \\
\hline & $\mathrm{C}^{1}$ & $\mathrm{D}^{2}$ & $\mathrm{ECP}_{125}{ }^{3}$ & $\mathrm{ECP}_{250}$ & $\mathrm{ECP}_{500}$ & & \\
\hline \multicolumn{8}{|c|}{ Yolk content, \% } \\
\hline 32 wk & 26.2 & 26.5 & 25.8 & 26.6 & 26.4 & 0.184 & 0.720 \\
\hline $44 \mathrm{wk}$ & 26.5 & 26.1 & 26.3 & 26.8 & 26.2 & 0.212 & 0.874 \\
\hline \multicolumn{8}{|c|}{ Albumen content, $\%$} \\
\hline $32 \mathrm{wk}$ & 63.4 & 63.7 & 63.4 & 62.8 & 62.9 & 0.201 & 0.632 \\
\hline 44 wk & 63.7 & 64.7 & 64.3 & 63.8 & 64.6 & 0.233 & 0.550 \\
\hline \multicolumn{8}{|c|}{ Shell content, \% } \\
\hline 32 wk & 10.5 & 9.8 & 10.8 & 10.6 & 10.7 & 0.113 & 0.064 \\
\hline 44 wk & 9.8 & 9.1 & 9.4 & 9.4 & 9.2 & 0.090 & 0.216 \\
\hline \multicolumn{8}{|c|}{ Shell thickness, mm } \\
\hline $32 \mathrm{wk}$ & $0.337^{\mathrm{ab}}$ & $0.305^{\mathrm{b}}$ & $0.334^{\mathrm{ab}}$ & $0.343^{\mathrm{ab}}$ & $0.369^{\mathrm{a}}$ & 0.006 & 0.019 \\
\hline $44 \mathrm{wk}$ & 0.397 & 0.375 & 0.380 & 0.384 & 0.380 & 0.003 & 0.075 \\
\hline \multicolumn{8}{|c|}{ Shell strength, $N$} \\
\hline 44 wk & 35.76 & 32.84 & 31.59 & 35.22 & 33.36 & 1.116 & 0.769 \\
\hline \multicolumn{8}{|c|}{ Haugh units } \\
\hline 32 wk & 74.4 & 76.6 & 80.8 & 71.4 & 75.9 & 1.252 & 0.183 \\
\hline $44 \mathrm{wk}$ & 67.2 & 66.7 & 66.8 & 70.1 & 68.8 & 1.357 & 0.928 \\
\hline \multicolumn{8}{|c|}{ Yolk colour, points } \\
\hline $32 \mathrm{wk}$ & 12.5 & 12.4 & 12.8 & 12.6 & 12.4 & 0.097 & 0.721 \\
\hline $44 \mathrm{wk}$ & $11.3^{\mathrm{ac}}$ & $10.6^{\mathrm{b}}$ & $11.6^{\mathrm{a}}$ & $11.0^{\mathrm{bc}}$ & $10.9^{\mathrm{bc}}$ & 0.083 & 0.001 \\
\hline \multicolumn{8}{|c|}{ Toe ash,\% } \\
\hline 44 wk & 12.47 & 12.06 & 12.43 & 12.76 & 12.85 & 0.104 & 0.121 \\
\hline
\end{tabular}


Statistically significant $(\mathrm{P}<0.01)$ differences in egg yolk colour were noted at the end of the experiment. The most desirable values of this parameter were obtained in treatments $\mathrm{ECP}_{125}$ and $\mathrm{C}$, and least desirable - in treatment D. In week 12 of the laying period, shell thickness was lowest in the D treatment compared with the remaining treatments, but the observed difference was significant only with respect to treatment $\mathrm{ECP}_{500}$ (with the highest inclusion of $E$. coli phytase), reaching $21 \%$. The same trend was observed in week 24 of the laying period, but the differences between treatments were statistically non-significant. Żyła et al. (2005) observed significantly effect of adding of 6-phytase to hen's diets on shell breaking strength in comparison to negative control group, what was only numerically in present study in $\mathrm{ECP}_{250}$ and $\mathrm{ECP}_{500}$ treatments (Table 6). There were obtained numerical differences in toe ash content, however they were not statistically confirmed (Table 6).

\section{CONCLUSIONS}

The results of the present experiment indicate that the supplementation of phosphorus deficient diets for laying hens with Escherichia coli-derived 6-phytase expressed in Pichia pastoris (Optiphos), in particular at a level of 125-250 FTU/ $\mathrm{kg}$ feed, improved the utilization of dietary phosphorus, therefore enabling to reduce the addition of non-phytate phosphorus to the diets without decreasing the performance parameters of birds.

\section{REFERENCES}

Augspurger N.R., Webel D.M., Baker D.H., 2007. An Escherichia coli phytase expressed in yeast effectively replaces inorganic phosphorus for finishing pigs and laying hens. J. Anim. Sci. 85, 1192-1198

Beutler A.L., 2009. The efficacy of Quantum ${ }^{\mathrm{TM}}$ phytase in laying hens fed corn-soybean meal based diets. MSc Thesis. University of Saskatchewan (Canada)

Boling S.D., Douglas M.W., Johnson M.L., Wang X., Parsons C.M., Koelkebeck K.W., Zimmerman R.A., 2000. The effects of dietary available phosphorus levels and phytase on performance of young and older laying hens. Poultry Sci. 79, 224-230

Eeckhout W., De Paepe M., 1994. Total phosphorus, phytate-phosphorus and phytase activity in plant feedstuffs. Anim. Feed Sci. Tech. 47, 19-29

Fiske C.H., Subbarow Y., 1925. The colorimetric determination of phosphorus. J. Biol. Chem. 66, $375-400$

Gordon R.W., Roland D.A., 1997. Performance of commercial laying hens fed various phosphorus levels, with and without supplemental phytase. Poultry Sci. 76, 1172-1177

Han Y., Wilson D.B., Lei X.G., 1999. Expression of an Aspergillus niger phytase gene (phyA) in Saccharomyces cerevisiae. Appl. Environ. Microbiol. 65, 1915-1918 
Hughes A.L., Dahiya J.P., Wyatt C.L., Classen H.L., 2008. The efficacy of Quantum phytase in a forty-week production trial using White Leghorn laying hens fed corn-soybean meal-based diets. Poultry Sci. 87, 1156-1161

Jalal M.A., Scheideler S.E., 2001. Effect of supplementation of two different sources of phytase on egg production parameters in laying hens and nutrient digestibility. Poultry Sci. 80, 1463-1471

Jeroch H., Peter W., 1994. Zur Wirksamkeit mikrobieller Phytase zu Legehennenrationen auf Maisbzw. Weizenbasis. Bodenkultur 45, 361-368

Kozłowski K., Jankowski J., Jeroch H., 2009. Efficacy of different phytase preparations in broiler rations. Pol. J. Vet. Sci. 12, 389-393

Kozłowski K., Jankowski J., Jeroch H., 2010a. Efficacy of different levels of Escherichia coli phytase in broiler diets with a reduced P content. Pol. J. Vet. Sci. 13, 431-436

Kozłowski K., Jankowski J., Jeroch H., 2010b. Efficacy of Escherichia coli-derived phytase on performance, bone mineralization and nutrient digestibility in meat-type turkeys. Vet. Med. Zoot. 52, 59-66

Liu N., Liu G.H., Li F.D., Sands J.S., Zhang S., Zheng A.J., Ru Y.J., 2007. Efficacy of phytases on egg production and nutrient digestibility in layers fed reduced phosphorus diets. Poultry Sci. $86,2337-2342$

LTZ , 2010. Lohmann Tierzucht GmbH. Manual of Lohmann Brown Hens. www.ltz.de

Maenz D.D., Classen H.L., 1998. Phytase activity in the small intestinal brush border membrane of the chicken. Poultry Sci. 77, 557-563

Marounek M., Skřivan M., Dlouhá G., Břeňová N., 2008. Availability of phytate phosphorus and endogenous phytase activity in the digestive tract of laying hens 20 and 47 weeks old. Anim. Feed Sci. Tech. 146, 353-359

NRC, 1994. Nutrient Requirements of Poultry. $9^{\text {th }}$ Edition. National Academy Press. Washington, DC

Oloffs K., Cossa J., Jeroch H., 2000a. Phosphorus utilization from different vegetable feedstuffs by laying hens. Arch. Geflügelk. 64, 24-28

Oloffs K., Cossa J., Jeroch H., 2000b. The importance of native phytase activity in wheat on the phosphorus utilization in broilers and laying hens. Arch. Geflügelk. 64, 157-161

Oloffs K., Dänicke S., Zachmann R., Jeroch H., 1997. Zur Wirksamkeit mikrobieller Phytase zu einer Legehennenration auf Maisbasis. Agribiol. Res. 50, 249-256

Ravindran V., Bryden W.L., Kornegay E.T., 1995. Phytin: Occurrence, bioavailability and implications in poultry nutrition. Poultry Avian Biol. Rev. 6, 125-143

Selle P.H., Ravindran V., 2007. Microbial phytase in poultry nutrition. Anim. Feed Sci. Tech. 135, $1-41$

Simons P.C.M., Versteegh H.A.J., 1993. The effect of addition of low doses of microbial phytase to layer feed on the technical results and skeleton and eggshell quality. Spelderholt Publication, No. 589 (NL)

Singh P.K., 2008. Significance of phytic acid and supplemental phytase in chicken nutrition: A review. World Poultry Sci. J. 64, 553-580

Smulikowska S., Rutkowski A. (Editors), 2005. Nutrient Requirements of Poultry. Feeding Recommendations and Nutritive Value of Feed (in Polish). $4^{\text {th }}$ Edition. The Kielanowski Institute of Animal Physiology and Nutrition, Polish Academy of Sciences, Jabłonna (Poland)

StatSoft Inc., 2009. Statistica (data analysis software system) Version 9.0.www.statsoft.com

Van der Klis J.D., Versteech H.A.J., Simons P.C.M., Kies A.K., 1997. The efficacy of phytase in corn-soybean meal diets for laying hens. Poultry Sci. 76, 1535-1542

Vogt H., 1992. Dietary phosphorus levels for cage hens. Arch. Geflügelk. 56, 264-270

Whiteside P.J., Milner B.A.,1984. Pye Unicam Atomic Absorption Data Book. $6^{\text {th }}$ Edition. Pye Unicam Ltd. Cambridge (UK) 
Wu G., Liu Y., Bryant M.M., Roland Jr. D.A., 2006. Comparison of Natuphos and Phyzyme as phytase sources for commercial layers feed corn-soy diet. Poultry Sci. 85, 64-69

Żyła K., Mika M., Koreleski J., Świątkiewicz S., 2005. Degree of phytate conversion and type of phytase A modify production parameters and egg shell quality in laying hens. J. Anim. Feed Sci., Suppl. 1, 515-518 